\title{
Perlakuan Benih Cabai (Capsicum annuum L.) dengan Rizobakteri secara Tunggal atau Kombinasi dapat Mengendalikan Phytophthora capsici dan Meningkatkan Pertumbuhan Tanaman
}

\section{Seed Treatments of Hot Pepper (Capsicum annuum L.) using Rhizobacteria Singly or in Combination Controlled Phytophthora capsici and Improved Plant Growth}

\author{
Farih Najah Rosadiah ${ }^{1}$, Satriyas Ilyas ${ }^{1 *}$, dan Dyah Manohara ${ }^{2}$
}

Diterima 20 Januari 2015/Disetujui 9 Maret 2015

\begin{abstract}
Seed treatment of hot pepper using rhizobacteria is an alternative to fungicide use in controlling phytophthora rot disease. The objectives of this research were to evaluate: (1) the effectiveness of rhizobacteria isolates in inhibiting Phytophthora capsici growth and (2) the effect of seed treatment using rhizobacteria on plant growth, and incidence of phytophthora blight disease. This research consisted of two experiments, all experiments were arranged in completely randomized design using one factor. The first experiment (in vitro) consisted of nine levels i.e. seven combination isolates of rhizobacteria, metalaxyl and control. The second experiment (in the green house) consisted of six levels of seed treatments i.e. ST116B rhizobacteria, CM8 rhizobacteria, $S T 116 B+C M 8$ rhizobacteria, metalaxyl, positive control and negative control. Results of in vitro experiment showed that all rhizobacteria, single or combinations, were able to inhibit $\underline{P}$. capsici growth. The highest inhibition were shown by CM8, ST116B $+C M 8$, and ST116B consecutively. Seed treatments of hot pepper using ST116B, CM8, and ST116B +CM8 rhizobacteria increased the number of leaves 6 weeks after transplanting and reduced the incidence of phytophthora blight disease. There were no significant differences whether the rhizobacteria was applied singly or in combination of the two. Rhizobacteria ST116B was suggested for pepper seed treatment before planting.
\end{abstract}

Keywords: metalaxyl, phytophthora blight disease, rhizobacteria

\begin{abstract}
ABSTRAK
Perlakuan benih cabai menggunakan rizobakteri merupakan alternatif pengganti fungisida dalam mengendalikan penyakit busuk phytophthora, yang disebabkan oleh cendawan patogen Phytophthora capsici. Penelitian ini bertujuan (1) mengevaluasi keefektifan kombinasi isolat rizobakteri dalam menghambat pertumbuhan $P$. capsici, dan (2) mengetahui pengaruh perlakuan benih dengan rizobakteri dalam meningkatkan vigor benih dan pertumbuhan tanaman, serta dalam mengurangi kejadian penyakit busuk phytophthora. Penelitian ini terdiri atas dua tahap percobaan, menggunakan rancangan acak lengkap satu faktor. Percobaan pertama (in vitro) terdiri atas sembilan taraf yaitu tujuh kombinasi isolat rizobakteri, metalaksil, dan tanpa perlakuan (kontrol). Percobaan kedua (di rumah kaca) terdiri atas enam taraf perlakuan benih yaitu rizobakteri ST116B, CM8, ST116B + CM8, metalaksil, kontrol positif, dan kontrol negatif. Hasil percobaan in vitro, semua perlakuan rizobakteri baik tunggal maupun yang dikombinasikan mampu menghambat pertumbuhan patogen $P$. capsici. Persentase daya hambat tertinggi berturut-turut ditunjukkan oleh isolat rizobakteri CM8, kombinasi isolat rizobakteri ST116B + CM8, dan isolat rizobakteri ST116B. Perlakuan benih dengan rizobakteri ST116B, CM8, dan ST116B + CM8 tidak dapat meningkatkan vigor benih, namun secara nyata meningkatkan pertambahan jumlah daun pada minggu ke enam
\end{abstract}

\footnotetext{
${ }^{1}$ Departemen Agronomi dan Hortikultura, Fakultas Pertanian, Institut pertanian Bogor

(Bogor Agricultural University), Jl. Meranti, Kampus IPB Darmaga, Bogor 16680, Indonesia

Telp.\&Faks. 62-251-8629353*Penulis untuk koresponden: satriyas252@gmail.com

${ }^{2}$ Balai Penelitian Tanaman Rempah dan Obat (Balittro), Kementerian Pertanian. Jl. Tentara Pelajar No. 3, Bogor, Indonesia.
} 
setelah pindah tanam, dan menurunkan kejadian penyakit busuk phytophthora. Tidak terdapat perbedaan nyata pengaruh rizobakteri yang diaplikasikan secara tunggal maupun kombinasi dua isolat. Rizobakteri ST116B disarankan untuk digunakan dalam perlakuan benih cabai sebelum tanam.

Kata kunci: metalaksil, penyakit busuk phytophthora, rizobakteri

\section{PENDAHULUAN}

Penggunaan benih bermutu rendah dan terinfeksi penyakit merupakan salah satu penyebab produktivitas cabai yang rendah di Indonesia. Phythoptora capsici merupakan patogen penyebab busuk phytophthora pada cabai, tomat, ketimun, labu-labuan, dan terong (Louws et al., 2002). Pengendalian patogen ini masih sulit karena metode pengendalian masih terbatas, patogen bersifat terbawa benih dan juga bersifat tular tanah (Miller et al., 1996; Roberts et al., 2000; Louws et al., 2002). Menurut Ilyas (2006), keberadaan patogen terbawa benih dapat menghambat perkecambahan dan mengakibatkan epidemi penyakit karena transmisi patogen dari benih ke tanaman, sehingga dapat menimbulkan dampak negatif pada kualitas dan hasil tanaman. Menurut Wiyono (2011) kehilangan hasil cabai di daerah dataran tinggi Tegal pada tahun 2010 akibat serangan cendawan $P$. capsici mencapai $100 \%$. Penyakit busuk phytophthora juga merupakan penyakit penting di beberapa negara. Granke et al. (2012) menyebutkan bahwa patogen ini telah tersebar di beberapa daerah di Amerika dan dunia. Kehilangan hasil akibat serangan $P$. capsici pada tanaman labu siap panen seluas 32 hektar mencapai $90 \%$ di Michigan.

Infeksi $P$. capsici pada cabai dapat terjadi beberapa hari sebelum gejala penyakit muncul. Patogen dapat menyerang melalui akar atau tajuk tanaman dengan gejala yang muncul seperti luka busuk yang secara cepat berkembang dan menyebabkan bercak berbentuk korset pada batang, tanaman kemudian layu dan mati. Patogen yang menginfeksi tanaman juga dapat menimbulkan luka busuk pada buah dan daun. Ada kalanya buah dan daun tersebut akan ditutupi oleh spora cendawan $P$. capsici (Hausbeck et al., 2014). Patogen yang telah menyerang tanaman dapat memproduksi inokulum lebih banyak yang dapat tersebar ke bagian tanaman di sekitarnya melalui hujan atau angin (Louws et al., 2002).
Benih bermutu varietas unggul merupakan kunci utama keberhasilan suatu usaha tani. Mutu benih menyangkut mutu genetis, fisik, fisiologis dan patologis (kesehatan benih) (Ilyas, 2012). Peningkatan mutu benih dan bibit dapat dilakukan melalui perlakuan benih (seed treatment). Salah satu tujuan perlakuan benih adalah untuk memperbaiki perkecambahan benih dan melindungi benih dari hama dan penyakit. Saat ini perlakuan benih umumnya menggunakan fungisida sintetis, akan tetapi seiring kesadaran masyarakat akan bahaya lingkungan dan kesehatan, maka penggunaannya mulai dikurangi dan beralih pada penggunaan agens hayati antagonis yang dapat menghambat pertumbuhan patogen serta meningkatkan vigor benih dan pertumbuhan tanaman.

Beberapa jenis rizobakteri dilaporkan mampu menghasilkan hormon tumbuh seperti IAA, melarutkan fosfat, serta memproduksi enzim ekstraseluler (kitinase, protease dan selulase), HCN, dan senyawa siderofor. Kemampuan rizobakteri tersebut berhubungan dengan peran rizobakteri sebagai pemacu pertumbuhan tanaman serta perannya sebagai agens antagonis dalam menghambat patogen tanaman (Sutariati et al., 2006b; Syamsuddin, 2010). Penggunaan mikroorganisme melalui aplikasi pada benih sebelum tanam secara nyata dapat meningkatkan produksi cabai (Ilyas, 2006).

Penelitian Ibrahim et al. (2014) menyebutkan bahwa perlakuan benih menggunakan rizobakteri ST116B, ST156 dan E3 nyata meningkatkan vigor benih cabai pada tolok ukur indeks vigor. Rizobakteri ST116B mampu meningkatkan pertumbuhan tanaman pada tolok ukur jumlah daun dan berpotensi mengendalikan penyakit busuk phytophthora pada tanaman cabai. Sebagai kelanjutan dari penelitian Ibrahim et al. (2014), penelitian ini bertujuan untuk mengevaluasi keefektifan kombinasi isolat rizobakteri ST116B, ST156 dan CM8 dalam menghambat pertumbuhan $P$. capsici secara in vitro. Tiga kombinasi rizobakteri terbaik yang efektif menghambat pertumbuhan $P$. capsici secara in vitro digunakan untuk 
melapisi benih cabai (seed treatment) dengan tujuan untuk mengendalikan $P$. capsici serta untuk meningkatkan pertumbuhan tanaman cabai.

\section{BAHAN DAN METODE}

Penelitian ini dilaksanakan di Laboratorium Penyakit Balittro (Balai Penelitian Tanaman Rempah dan Obat), Laboratorium Kesehatan Benih, Departemen Agronomi dan Hortikultura dan Rumah Kaca Cikabayan, Departemen Proteksi Tanaman, Fakultas Pertanian, Institut Pertanian Bogor. Penelitian dilaksanakan pada bulan April hingga Desember 2014. Penelitian ini terdiri atas dua percobaan. Percobaan pertama (in vitro) terdiri atas sembilan taraf yaitu tujuh kombinasi isolat rizobakteri, metalaksil dan kontrol. Percobaan kedua (di rumah kaca) terdiri atas enam taraf perlakuan benih yaitu rizobakteri ST116B, CM8, ST116B + CM8, metalaksil, kontrol positif dan kontrol negatif.

Benih yang digunakan pada penelitian ini adalah benih cabai varietas Laris produksi PT. East West Seed Indonesia yang diperoleh dari salah satu toko pertanian di Lampung. Varietas Laris dipilih karena rentan terhadap serangan patogen $P$. capsici (Yunianti et al., 2007). Daya berkecambah benih sesaat sebelum benih ditanam adalah sebesar $63 \%$.

\section{Percobaan 1. Evaluasi Keefektifan Kombinasi Isolat Rizobakteri sebagai Antagonis P. capsici secara In Vitro}

Suspensi sel rizobakteri ST116B, ST156 dan CM8 (koleksi Balittro) dikombinasikan dengan cara mencampurkan dua atau tiga suspensi sel rizobakteri yang masing-masing berjumlah $50 \mathrm{ml}$ ke dalam sebuah erlenmeyer, kemudian erlenmeyer dikocok hingga suspensi sel tercampur merata. Perlakuan kombinasi rizobakteri secara rinci adalah sebagai berikut:

1. Rizobakteri ST116B

2. Rizobakteri ST156

3. Rizobakteri CM8

4. Kombinasi ST116B + ST156

5. Kombinasi ST116B + CM8

6. Kombinasi ST156 + CM8

7. Kombinasi ST116B + ST156 + CM8

8. Metalaksil, dijadikan sebagai pembanding

9. Kontrol
Uji keefektifan kombinasi isolat rizobakteri sebagai antagonis $P$. capsici dilakukan dengan metode dual culture. Isolat $P$. capsici yang telah ditumbuhkan pada media PDA (potato dextrose agar) dipotong dengan diameter $0.5 \mathrm{~cm}$ kemudian dipindahkan ke media PDA baru dengan jarak $3 \mathrm{~cm}$ dari tepi cawan petri. Isolat rizobakteri yang diuji digoreskan memanjang dengan jarak $5 \mathrm{~cm}$ dari isolat $P$. capsici. Untuk perlakuan metalaksil (Saromil berbahan aktif 35\% metalaksil) dilakukan dengan merendam paper disk $\varnothing 0.5$ $\mathrm{cm}$ ke dalam suspensi metalaksil $800 \mathrm{ppm}$ selama 5 menit, kemudian diletakkan dengan jarak $5 \mathrm{~cm}$ dari isolat $P$. capsici. Sebagai kontrol, isolat $P$. capsici ditumbuhkan pada media PDA tanpa perlakuan rizobakteri ataupun perlakuan metalaksil. Pengamatan dilakukan pada hari ke-3, hari ke-6 dan hari ke-8 terhadap pertumbuhan koloni patogen $P$. capsici dan zona bening (ruang di antara pertumbuhan $P$. capsici dan rizobakteri). Pengamatan zona bening dilakukan dengan cara mengukur jarak antara ujung hifa $P$. capsici dan goresan rizobakteri menggunakan penggaris $(\mathrm{cm})$. Persentase daya hambat $(\mathrm{DH})$ rizobakteri terhadap pertumbuhan patogen $P$. capsici dihitung dengan rumus:

Keterangan:

$$
\mathrm{DH}=\frac{\mathrm{R} 1-\mathrm{R} 2}{\mathrm{R} 1} \times 100 \%
$$

$\mathrm{R} 1=$ jari-jari pertumbuhan patogen tanpa rizobakteri (kontrol)

$\mathrm{R} 2=$ jari-jari pertumbuhan patogen ke arah rizobakteri (Syamsuddin, 2010).

Percobaan in vitro ini menggunakan rancangan acak lengkap (RAL) satu faktor yaitu isolat rizobakteri terdiri atas sembilan taraf: tujuh perlakuan kombinasi isolat rizobakteri, perlakuan metalaksil, dan kontrol. Setiap perlakuan diulang lima kali sehingga terdapat 45 satuan percobaan. Tiga perlakuan isolat rizobakteri terbaik yang berpotensi menghambat $P$. capsici akan digunakan untuk percobaan selanjutnya.

Percobaan 2. Pengaruh Perlakuan Benih dalam Meningkatkan Pertumbuhan Tanaman dan Mengurangi Persentase Kejadian Penyakit Busuk Phytophthora di Rumah Kaca 


\section{Perlakuan Benih dengan Rizobakteri}

Benih cabai varietas Laris produksi PT. East West Seed Indonesia yang digunakan berasal dari salah satu toko pertanian di Lampung dengan daya berkecambah saat digunakan $63 \%$. Sebelum diberi perlakuan, benih terlebih dahulu didisinfeksi dengan merendam benih dalam alkohol $70 \%$ selama 3 menit. Selanjutnya benih dicuci sebanyak tiga kali dengan akuades steril dan dikeringanginkan dalam laminar air flow cabinet selama 60 menit. Benih yang telah dikeringanginkan diberi perlakuan dengan cara merendam benih dalam $50 \mathrm{~mL}$ suspensi isolat rizobakteri atau $50 \mathrm{~mL}$ suspensi metalaksil $(800 \mathrm{ppm}$ ) atau $50 \mathrm{~mL}$ air steril (sebagai kontrol) selama 24 jam pada suhu $26^{\circ} \mathrm{C}$. Benih yang telah diberi perlakuan selanjutnya dikering-anginkan selama 60 menit sebelum ditanam (Syamsuddin, 2010). Suspensi sel rizobakteri yang digunakan dibuat dengan menginkubasi masing-masing rizobakteri dalam $50 \mathrm{~mL}$ potato dextrose (PD) selama 48 jam, kemudian dilihat nilai optical density (OD) dengan menggunakan spektrofotometer agar diketahui kerapatan rizobakteri tersebut. Kerapatan dari ketiga rizobakteri tersebut adalah $10^{9}$ cfu. Benih yang sudah diberi perlakuan pelapisan rizobakteri kemudian disemai pada tray semai yang berisi campuran tanah dan pupuk kandang $(1: 1 \mathrm{v} / \mathrm{v})$ di rumah kaca. Bibit cabai dipindahkan ke polibag saat berumur 35 HST.

\section{Penanaman Bibit di Polibag}

Sebanyak 30 bibit per perlakuan kemudian dipindahkan ke polibag (satu bibit per polibag) berukuran $30 \mathrm{~cm}$ x $35 \mathrm{~cm}$. Khusus pada perlakuan kontrol, dipindahkan 30 bibit untuk bibit tanpa perlakuan dan tanah tidak diinokulasi P. capsici (kontrol negatif), dan 30 untuk bibit tanpa perlakuan rizobakteri tetapi tanah diinokulasi P. capsici (kontrol positif). Media tanam yang digunakan adalah campuran tanah dan pupuk kandang $(4: 1 \mathrm{v} / \mathrm{v})$. Media tanam yang berisi bibit tersebut diletakkan secara teratur berjarak $30 \mathrm{~cm}$ x 50 $\mathrm{cm}$. Penyiraman dilakukan setiap hari agar pertumbuhan dan perkembangan bibit normal. Pemupukan tanaman dilakukan pada 2 MSP dan 6 MSP menggunakan pupuk NPK mutiara (15:15:15) sebanyak $50 \mathrm{~mL}$ per tanaman dengan konsentrasi $2 \mathrm{~g} \mathrm{~L}^{-1}$.
Penyiapan Tanah Inokulum dan Infestasi Tanah pada Tanaman

Tanah inokulum dibuat dengan mengering-anginkan tanah sebanyak $4 \mathrm{~kg}$, kemudian dicampur dengan $4 \%$ oat meal dan diberi air secukupnya hingga membasahi seluruh campuran tanah dan oat meal. Tanah tersebut kemudian disterilkan dengan autoklaf suhu $120{ }^{\circ} \mathrm{C}$ selama 30 menit. Potongan biakan diinfestasikan ke tanah yang sudah steril dan diinkubasi pada ruangan suhu $23-25{ }^{\circ} \mathrm{C}$ selama dua minggu (Manohara 1988). Infestasi tanah inokulum dilakukan saat bibit berumur 2 minggu setelah pindah tanam, dengan cara sebanyak $10 \mathrm{~g}$ tanah inokulum disebar di sekeliling tanaman dan pangkal batang tidak dilukai (Ibrahim et al., 2014). Pengamatan dilakukan pada 1-6 MSP (minggu setelah pindah tanam) pada tolok ukur pertambahan tinggi tanaman dan pertambahan jumlah daun, serta pada 1-4 MSI (minggu setelah infestasi tanah inokulum) pada tolok ukur kejadian penyakit. Pengendalian hama dilakukan dengan menyemprotkan insektisida berbahan aktif deltametrin $25 \mathrm{~g} \mathrm{~L}^{-1}$ dengan konsentrasi $0.5 \mathrm{ml} \mathrm{L} \mathrm{L}^{-1}$ setiap dua minggu sekali. Pengendalian gulma dilakukan secara manual yakni dengan pencabutan.

Percobaan kedua menggunakan RAL satu faktor yaitu perlakuan benih dengan isolat rizobakteri terdiri atas enam taraf: isolat rizobakteri ST116B, isolat rizobakteri CM8, isolat rizobakteri ST116B + CM8, metalaksil, tanpa perlakuan benih dan tanpa inokulasi $P$. capsici (kontrol negatif), tanpa perlakuan benih dan diinokulasi $P$. capsici (kontrol positif). Setiap perlakuan diulang tiga kali sehingga terdapat 18 satuan percobaan. Setiap satuan percobaan menggunakan 10 bibit sehingga dibutuhkan 180 bibit cabai.

\section{HASIL DAN PEMBAHASAN}

\section{Percobaan 1. Evaluasi Keefektifan Kombinasi Isolat Rizobakteri sebagai Antagonis $P$. capsici secara In Vitro}

Seluruh isolat rizobakteri yang diujikan terbukti memiliki kemampuan menghambat pertumbuhan $P$. capsici. Daya hambat terhadap $P$. capsici terlihat pada pertumbuhan koloni $P$. capsici pada perlakuan rizobakteri yang lebih lambat dibandingkan kontrol 
( $P$. capsici ditumbuhkan pada media PDA tanpa perlakuan rizobakteri ataupun metalaksil) (Gambar 1A). Saat 8 HSI (hari setelah inkubasi), jari-jari koloni $P$. capsici pada kontrol telah memenuhi permukaan dasar cawan petri, sedangkan pertumbuhan jari-jari koloni $P$. capsici pada perlakuan rizobakteri dan metalaksil terhambat (Gambar 1A). Jarijari $P$. capsici pada beberapa perlakuan rizobakteri mampu tumbuh melewati goresan rizobakteri, namun ada juga jari-jari $P$. capsici pada beberapa perlakuan rizobakteri yang tidak mampu tumbuh melewati goresan rizobakteri, sehingga terbentuk zona bening (ruang kosong di antara pertumbuhan $P$. capsici dan rizobakteri).

Panjang zona bening yang terbentuk pada beberapa perlakuan rizobakteri yang diuji berbeda-beda (Gambar 1B), hal ini menunjukkan bahwa setiap rizobakteri memiliki kemampuan yang berbeda-beda dalam menghasilkan senyawa metabolit sekunder yang bersifat antagonis terhadap $P$. capsici. Pertumbuhan $P$. capsici yang terhambat oleh rizobakteri diduga karena rizobakteri mampu memproduksi senyawa metabolit sekunder yang bersifat antagonis terhadap pertumbuhan $P$. capsici. Menurut Syamsuddin (2010) efektifitas penghambatan rizobakteri terhadap patogen melibatkan banyak mekanisme, salah satunya yakni berhubungan dengan kemampuan isolat rizo-bakteri dalam mensekresikan enzim ekstra-seluler (kitinase, protease dan selulase) khususnya protease dan selulase, serta produksi HCN. Sutariati et al. (2006a) melaporkan bahwa enzim kitinase tidak menunjukkan peran dalam pengham-batan cendawan patogen Colletotrichum capsici oleh isolat rizobakteri dari kelompok Bacillus spp., Pseudomonas spp., dan Serratia spp.. Ketiga spesies rizobakteri tersebut terbukti mampu memproduksi senyawa $\mathrm{HCN}$ yang bersifat toksik terhadap patogen $C$. Capsici.

Secara mikroskopis terlihat perbedaan bentuk antara ujung hifa cendawan $P$. capsici pada perlakuan rizobakteri, perlakuan metalaksil dan kontrol (Gambar 2). Diby et al. (2005) menjelaskan bahwa beberapa strain Pseudomonas fluoroscens dan Trichoderma spp. mampu berperan sebagai agens antagonis terhadap patogen $P$. capsici dengan menghasilkan enzim mycolytic viz. $\beta-1,3$ glucanase, $\beta-14$ glucanase dan lipase. Beberapa strain $P$. fluoroscens menyebabkan koagulasi sitoplasma pada miselium $P$. capsici ketika dikulturkan secara bersama-sama. Selain itu $P$. fluoroscens juga dapat menghancurkan keseluruhan isi sitoplasma setelah dikulturkan secara bersamasama setelah 72 jam.

Seluruh isolat rizobakteri yang diujikan memiliki persentase daya hambat yang tinggi terhadap pertumbuhan $P$. capsici 8 hari setelah inkubasi, yakni $44 \%$ - $61 \%$ (Tabel 1). Berturut-turut perlakuan rizobakteri $\mathrm{CM} 8$, rizobakteri ST116B + CM8, dan rizobakteri ST116B merupakan perlakuan yang memiliki zona bening dan persentase daya hambat tertinggi terhadap $P$. capsici dibandingkan perlakuan lainnya. Perlakuan kombinasi rizobakteri tidak menunjukkan persentase daya hambat yang lebih tinggi dibandingkan perlakuan rizobakteri tunggal. Daya hambat tertinggi dan zona bening terpanjang sebagai respon perlakuan kombinasi rizobakteri ST116B + CM8 tidak berbeda nyata dengan perlakuan fungisida metalaksil. Dari hasil Percobaan 1 ini, perlakuan rizobakteri CM8, rizobakteri ST116B + CM8, dan rizobakteri ST116B terpilih untuk digunakan dalam melapisi benih pada percobaan berikutnya.
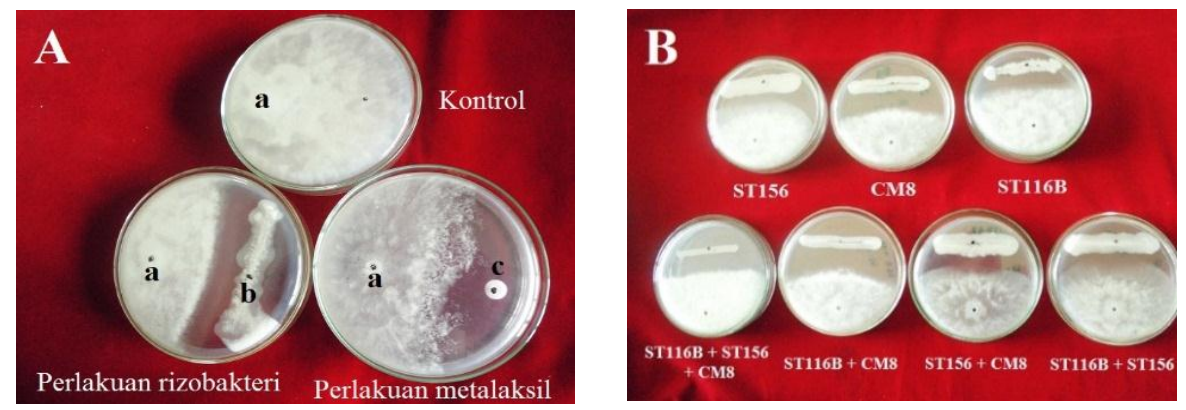

Gambar 1. Pertumbuhan koloni P. capsici (a), rizobakteri ST116B (b) dan paper disc Ø $0.5 \mathrm{~cm}$ yang telah direndam metalaksil 800 ppm (c) pada media PDA (A); perbedaan daya hambat beberapa rizobakteri terhadap $P$. capsici (B) 

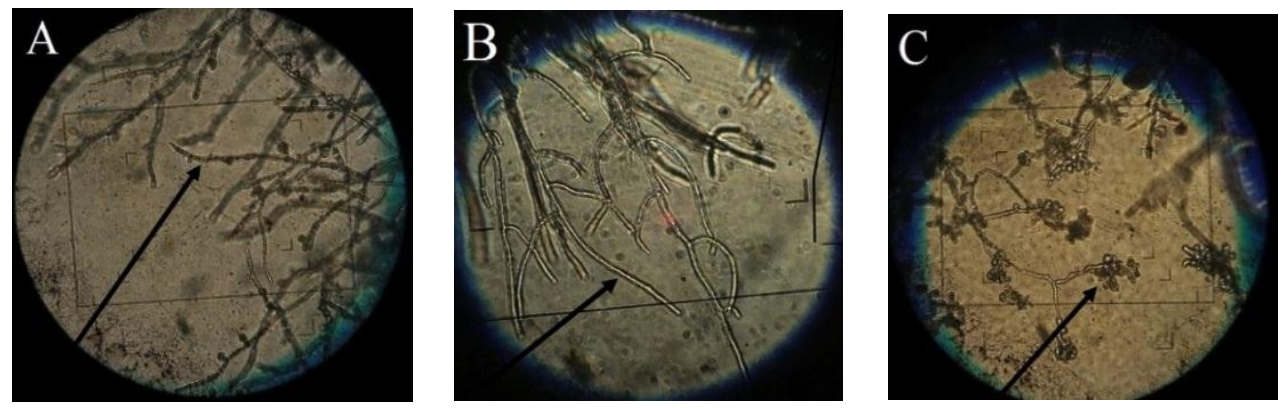

Gambar 2. Keragaan pertumbuhan hifa $P$. capsici pada media PDA: tanpa perlakuan (A), digoreskan rizobakteri kerapatan $10^{9} \mathrm{cfu}$, disintegrasi sitoplasma P. capsici (B), diletakkan paper disc $\varnothing$ $0.5 \mathrm{~cm}$ yang direndam metalaksil $800 \mathrm{ppm}$, ujung hifa abnormal (C). Mikroskop perbesaran $40 \times 10$.

Tabel 1. Kemampuan isolat rizobakteri menghambat pertumbuhan P. capsici secara in vitro pada 8 hari setelah inkubasi

\begin{tabular}{|c|c|c|c|c|}
\hline No & Perlakuan Rizobakteri & $\begin{array}{c}\text { Rata-rata Jari-Jari } \\
\text { Pertumbuhan } P . \text { capsici }(\mathrm{cm})\end{array}$ & $\begin{array}{l}\text { Daya Hambat terhadap } \\
\text { P. capsici }(\%)^{*}\end{array}$ & $\begin{array}{l}\text { Rata-rata Zona } \\
\text { Bening }(\mathrm{cm})^{*}\end{array}$ \\
\hline 1 & ST116B ${ }^{* *}$ & 3.34 & $52 c$ & $0.82 \mathrm{c}$ \\
\hline 2 & ST156 & 3.50 & $50 \mathrm{c}$ & $0.00 \mathrm{e}$ \\
\hline 3 & $\mathrm{CM} 8^{* *}$ & 2.70 & $61 \mathrm{a}$ & $1.86 \mathrm{a}$ \\
\hline 4 & ST116B + ST156 & 3.95 & $44 \mathrm{e}$ & $0.04 \mathrm{de}$ \\
\hline 5 & ST116B + CM8** & 3.02 & $57 \mathrm{~b}$ & $1.40 \mathrm{~b}$ \\
\hline 6 & ST156 + CM8 & 3.72 & $47 \mathrm{de}$ & $0.09 \mathrm{de}$ \\
\hline 7 & ST116B + ST156 + CM8 & 3.70 & $47 \mathrm{de}$ & $0.21 \mathrm{~d}$ \\
\hline 8 & Metalaksil & 2.55 & $65 \mathrm{a}$ & $1.93 \mathrm{a}$ \\
\hline \multirow[t]{3}{*}{9} & Kontrol & 7.00 & - & - \\
\hline & KK & - & 7.38 & 20.09 \\
\hline & F Hitung & - & 0.0001 & 0.0001 \\
\hline
\end{tabular}

Keterangan: *Angka pada kolom yang sama dengan huruf yang sama tidak berbeda nyata berdasarkan Duncan multiple range test (DMRT) pada taraf $\alpha=5 \%$; ** rizobakteri digunakan untuk percobaan selanjutnya.

Percobaan 2. Pengaruh Perlakuan Benih dalam Meningkatkan Pertumbuhan Tanaman dan Mengurangi Persentase Kejadian Penyakit di Rumah Kaca.

Tabel 2 menunjukkan bahwa seluruh perlakuan rizobakteri maupun metalaksil tidak memberikan pengaruh yang nyata terhadap pertambahan jumlah daun cabai pada 2-5 MSP. Benih dengan perlakuan pelapisan rizobakteri ST116B, CM8 dan ST116B + CM8 sebelum benih ditanam terbukti mampu meningkatkan pertambahan jumlah daun yang sangat nyata lebih tinggi dibandingkan kontrol positif (benih tanpa perlakuan rizobakteri dan tanah diinokulasi P. capsici) pada 6 MSP. Hal tersebut diduga berhubungan dengan peranan rizobakteri sebagai pemacu pertumbuhan tanaman atau PGPR (plant growth promoting rhizobacteria).
Menurut Tenuta (2004), kemampuan rizobakteri sebagai PGPR berhubungan erat dengan kemampuannya dalam memproduksi fitohormon seperti IAA, sitokinin, giberelin dan etilen dalam peranannya sebagai biostimulant. Selain itu, menurut McMillan (2007), kemampuan rizobakteri dalam menyediakan hara (biofertilizer) dengan menambahkan $\mathrm{N}_{2}$ dari udara secara asimbiosis, kemampuan melarutkan fosfat serta kemampuan mengoksidasi sulfur juga merupakan karakteristik rizobakteri dalam peranannya sebagai PGPR. Pada penelitian sebelumnya telah dilaporkan bahwa inokulasi benih dengan rizobakteri isolat Bacillus spp., Pseudomonas spp. dan Serratia spp. nyata meningkatkan jumlah daun cabai pada 6 MSP (Syamsuddin 2010). Ibrahim et al. (2014) juga melaporkan bahwa perlakuan benih dengan rizobakteri ST116B mampu meningkatkan pertumbuhan tanaman cabai pada tolok ukur jumlah daun. 
Tabel 2. Pengaruh perlakuan benih dengan rizobakteri terhadap pertambahan jumlah daun pada 2-6 MSP di polibag

\begin{tabular}{lccccl}
\hline \multirow{2}{*}{ Perlakuan Benih } & \multicolumn{5}{c}{ Pertambahan Jumlah Daun } \\
\cline { 2 - 6 } & 2 MSP & 3 MSP & 4 MSP & 5 MSP & 6 MSP \\
\hline ST116B & 2.5 & 0.7 & 1.8 & 5.3 & $8.4 \mathrm{a}$ \\
CM8 & 2.3 & 0.9 & 2.7 & 3.7 & $6.5 \mathrm{a}$ \\
ST116B + CM8 & 3.2 & 1.0 & 2.7 & 8.4 & $9.0 \mathrm{a}$ \\
Metalaksil & 2.8 & 1.0 & 4.1 & 7.2 & $2.1 \mathrm{~b}$ \\
Kontrol Positif $^{* *}$ & 2.5 & 1.7 & 1.7 & 10.2 & $2.8 \mathrm{~b}$ \\
Kontrol Negatif $^{* *}$ & 3.1 & 2.3 & 2.4 & 6.4 & $9.0 \mathrm{a}$ \\
KK & 17.1 & 21.0 & 37.2 & 24.1 & 9.5 \\
F Hitung & 0.9359 & 0.1637 & 0.8877 & 0.3121 & 0.0001 \\
\hline Ke
\end{tabular}

Keterangan: *Angka pada kolom yang sama diikuti dengan huruf yang sama tidak berbeda nyata berdasarkan Duncan multiple range test $(\mathrm{DMRT})$ pada taraf $\alpha=5 \%$; MSP $=$ minggu setelah pindah tanam; $* *$ kontrol positif (tanpa perlakuan rizobakteri dan tanah diinokulasi $P$. capsici), kontrol negatif (tanpa perlakuan rizobakteri dan tanah diinokulasi $P$. capsici); MSP = minggu setelah pindah tanam.

Hasil pengamatan pada 6 MSP (Tabel 2) juga menunjukkan bahwa perlakuan rizobakteri mampu mempertahankan laju pertumbuhan tanaman yang sakit sebagaimana laju pertumbuhan tanaman yang sehat. Hal tersebut terlihat pada tanaman yang diinokulasi $P$. capsici pada perlakuan rizobakteri ST116B, CM8 dan ST116B + CM8 memiliki laju pertambahan jumlah daun yang tidak berbeda nyata dengan kontrol negatif (tanaman yang tidak diinokulasi $P$. capsici namun benih tidak diberi perlakuan). Benih dengan perlakuan metalaksil menunjukkan nilai yang tidak berbeda nyata dengan kontrol positif (benih tanpa perlakuan dan tanah diinokulasi $P$. capsici), namun nyata lebih rendah dibandingkan benih dengan perlakuan rizobakteri. Hal tersebut diduga disebabkan karena metalaksil tidak dapat memproduksi senyawa PGPR sebagaimana yang bisa diproduksi oleh rizobakteri.

Tabel 3 menunjukkan perlakuan rizobakteri maupun metalaksil tidak berpengaruh secara nyata terhadap pertambahan tinggi tanaman cabai pada 2-4 MSP. Pertambahan tinggi tanaman saat 5 MSP pada perlakuan kontrol negatif (benih tanpa perlakuan dan tanah diinokulasi $P$. capsici) dan metalaksil menunjukkan nilai yang sangat nyata lebih tinggi dibanding perlakuan lainnya. Perlakuan rizobakteri dengan pertambahan tinggi tanaman yang lebih rendah dibanding perlakuan lainnya diduga karena fitohormon
IAA yang dihasilkan oleh rizobakteri lebih banyak terkonsentrasi pada daerah pertumbuhan daun daripada daerah pertumbuhan tinggi tanaman. Menurut Darmawan dan Baharsjah (2010) penyebaran auksin yang tidak merata dapat mengakibatkan terjadinya perbedaan rangsangan perpanjangan sel. Harjadi (1996) juga menjelaskan bahwa dominansi pucuk (apical dominance) merupakan penghambatan oleh titik tumbuh pada pertumbuhan tunas-tunas di bawahnya yang merupakan fungsi dari distribusi auksin.

Benih dengan perlakuan rizobakteri CM8 yang diinokulasi $P$. capsici memiliki nilai pertambahan tinggi tanaman saat $6 \mathrm{MSP}$ yang tidak berbeda nyata dengan kontrol negatif (benih tanpa perlakuan dan tanah tidak diinokulasi $P$. capsici). Hal tersebut menunjukkan bahwa perlakuan benih dengan rizobakteri CM8 mampu mempertahankan kemampuan tanaman cabai yang sakit untuk melakukan pertumbuhan sama dengan kemampuan pertumbuhan tanaman cabai yang sehat.

Pengamatan terhadap persentase kejadian penyakit dilakukan selama 28 hari sejak infestasi tanah inokulum $P$. capsici pada pangkal batang tanaman cabai. Gejala serangan $P$. capsici mulai terlihat pada saat 14 hari setelah infestasi. Perlakuan benih dengan rizobakteri terbukti mampu mengurangi tingkat serangan patogen $P$. capsici pada tanaman (Tabel 4). 
Tabel 3. Pengaruh perlakuan benih dengan rizobakteri terhadap pertambahan tinggi tanaman pada 26 MSP di polibag

\begin{tabular}{lccccc}
\hline \multirow{2}{*}{ Perlakuan Benih } & \multicolumn{5}{c}{ Pertambahan Tinggi Tanaman $(\mathrm{cm})^{*}$} \\
\cline { 2 - 6 } & $2 \mathrm{MSP}$ & $3 \mathrm{MSP}$ & $4 \mathrm{MSP}$ & $5 \mathrm{MSP}$ & $6 \mathrm{MSP}$ \\
\hline ST116B & 6.80 & 1.03 & 0.59 & $0.14 \mathrm{~b}$ & $0.21 \mathrm{bc}$ \\
CM8 & 6.80 & 1.50 & 0.56 & $0.23 \mathrm{~b}$ & $0.51 \mathrm{a}$ \\
ST116B + CM8 & 7.58 & 1.38 & 0.28 & $0.11 \mathrm{~b}$ & $0.11 \mathrm{c}$ \\
Metalaksil & 6.85 & 1.35 & 0.56 & $0.79 \mathrm{a}$ & $0.20 \mathrm{bc}$ \\
Kontrol Positif $^{* *}$ & 6.59 & 1.15 & 0.46 & $0.22 \mathrm{~b}$ & $0.17 \mathrm{bc}$ \\
Kontrol Negatif $^{* *}$ & 5.24 & 3.07 & 1.11 & $0.92 \mathrm{a}$ & $0.45 \mathrm{ab}$ \\
KK & 10.58 & 25.84 & 18.73 & 10.7 & 10.72 \\
F Hitung & 0.5427 & 0.3244 & 0.3482 & 0.0008 & 0.0416 \\
\hline
\end{tabular}

Keterangan: detil idem Tabel 2; data pada tabel sebelum diolah ditransformasi dengan rumus $\sqrt{\mathrm{x}+0.5}$.

Tabel 4. Pengaruh perlakuan rizobakteri pada benih terhadap kejadian penyakit saat 28 hari setelah infestasi inokulum $P$. capsici ke tanah

\begin{tabular}{lccc}
\hline \multirow{2}{*}{ Perlakuan Rizobakteri } & \multicolumn{3}{c}{ Kejadian Penyakit (\%) } \\
\cline { 2 - 4 } & 14 HSI & $21 \mathrm{HSI}$ & $28 \mathrm{HSI}$ \\
\hline ST116B & 3 & $3 \mathrm{ab}$ & $3 \mathrm{bc}$ \\
CM8 & 0 & $7 \mathrm{ab}$ & $7 \mathrm{abc}$ \\
CM8 + ST116B & 3 & $3 \mathrm{ab}$ & $3 \mathrm{bc}$ \\
Metalaksil & 0 & $10 \mathrm{a}$ & $10 \mathrm{ab}$ \\
Kontrol Positif & 3 & $13 \mathrm{a}$ & $17 \mathrm{a}$ \\
Kontrol Negatif & 0 & $0 \mathrm{~b}$ & $0 \mathrm{c}$ \\
KK & 244.9 & 72.6 & 74.9 \\
F Hitung & 0.7013 & 0.0435 & 0.0420 \\
\hline
\end{tabular}

Keterangan: detil idem Tabel 2; data pada tabel sebelum diolah ditransformasi dengan rumus arcsin $\sqrt{\mathrm{x}+0.5}$; HSI $=$ hari setelah infestasi.

Tabel 4 menunjukkan bahwa saat 21 HSI inokulum ke tanah, tanaman cabai yang diberikan perlakuan rizobakteri pada benih sebelum tanam mengalami persentase kejadian penyakit yang lebih rendah dibandingkan tanaman cabai pada kontrol positif (tanpa perlakuan rizobakteri dan tanah diinokulasi $P$. capsici). Saat 28 HSI, persentase kejadian penyakit pada perlakuan rizobakteri juga menunjukkan nilai yang lebih rendah dibandingkan kontrol positif. Hal tersebut diduga berhubungan dengan kemampuan rizobakteri dalam menghasilkan enzim ekstraselular, senyawa siderofor dan senyawa HCN. Penelitian Syamsuddin (2010) menyebutkan bahwa isolat rizobakteri yang didapat dari rizosfer tanaman cabai sehat mampu mensekresikan enzim ekstraselular serta memproduksi $\mathrm{HCN}$ dan siderofor sehingga mampu menghambat pertumbuhan patogen $P$. capsici. Enzim ekstraselular yang paling berperan ialah protease dan lipase. Sutariati et al. (2006a) juga melaporkan bahwa rizobakteri kelompok $P$. fluoroscens PG01 mampu menghambat pertumbuhan $C$. capsici melalui sintesis senyawa $\mathrm{HCN}$ yang bersifat toksik bagi patogen.

Jika dibandingkan kontrol positif, perlakuan benih dengan metalaksil menunjukkan persentase kejadian penyakit busuk phytophthora yang tidak berbeda nyata. Perlakuan benih dengan rizobakteri terbukti mampu menurunkan persentase kejadian penyakit yang lebih baik dibandingkan perlakuan benih dengan metalaksil. Menurut Syamsuddin (2010) meskipun metalaksil merupakan fungisida yang bersifat sistemik, namun efek pengendalian metalaksil berdurasi singkat tidak seperti halnya efek pengendalian yang diberikan oleh agens biokontrol yang bersifat lama dan mampu menginduksi ketahanan tanaman secara sistemik serta secara tidak langsung juga berperan sebagai pemacu pertumbuhan. 

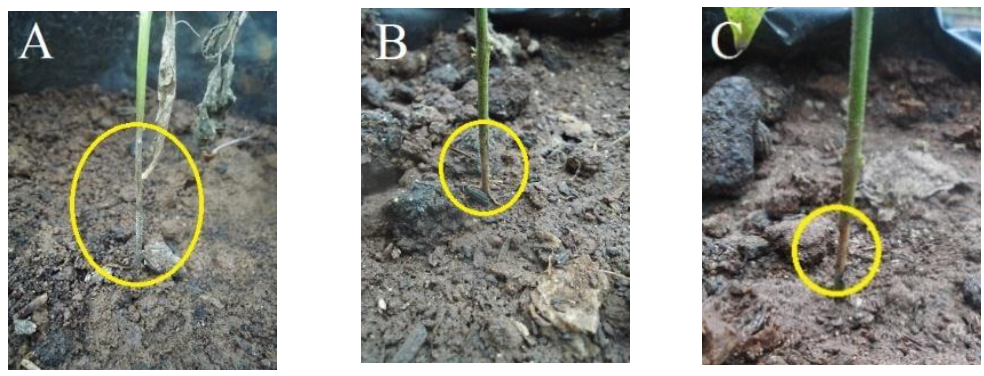

Gambar 3. Gejala serangan pada tanaman cabai: perubahan warna pangkal batang dari hijau menjadi coklat $(\mathrm{A}, \mathrm{B}, \mathrm{C})$

Gambar 3 menunjukkan gejala serangan pada batang bagian bawah yang mengalami perubahan warna dari hijau menjadi coklat, tanaman tersebut kemudian menjadi layu dan mati. Menurut Ibrahim et al. (2014) gejala serangan $P$. capsici berupa pangkal batang yang mengalami perubahan warna dari hijau menjadi coklat kemudian seluruh bagian daun layu, tanaman mengering dan selanjutnya tanaman mati.

\section{KESIMPULAN}

Semua perlakuan rizobakteri baik yang dikombinasikan maupun yang tunggal secara in vitro mampu menghambat pertumbuhan patogen $P$. capsici. Persentase daya hambat tertinggi berturut-turut ditunjukkan oleh isolat rizobakteri $\mathrm{CM} 8$, kombinasi isolat rizobakteri ST116B + CM8 dan isolat rizobakteri ST116B. Ketiga perlakuan benih dengan rizobakteri tersebut nyata meningkatkan pertambahan jumlah daun, dan menurunkan kejadian penyakit busuk phytophthora pada tanaman cabai. Tidak terdapat perbedaan nyata pengaruh rizobakteri yang diaplikasikan secara tunggal maupun kombinasi kedua rizobakteri.

\section{DAFTAR PUSTAKA}

Darmawan, J., J.S. Baharsjah. 2010. Dasar Dasar Fisiologi Tanaman SITC. Jakarta.

Diby, P., K.A. Saju, P.J. Jisha, Y.R. Sarma, A. Kumar, M. Anandaraj. 2005. Mycolytic enzymes produced by Pseudomonas fluoroscens and Trichoderma spp. against Phytophthora capsici, the foot rot pathogen of black pepper (Piper nigrum L.). Annals of Microbiology. 55(2):129-133.

Granke, L.L., L.Q. Ocampo. 2012. Advances in research on Phytophthora capsici on vegetable crops in the United States. Plant Disease. 95(11):1588-1600.

Harjadi, S.S. 1996. Pengantar Agronomi. PT Gramedia. Jakarta.

Hausbeck, M.K., Foster J.M., S.D. Linderman. 2014. Managing phytophthora on pepper. USDA NIFA Special Research Grant: Michigan State University Extension.

Ibrahim, A., S. Ilyas, D. Manohara. 2014. Perlakuan benih cabai (Capsicum annuит L.) dengan rizobakteri untuk mengendalikan Phytophthora capsici, meningkatkan vigor benih, dan pertumbuhan tanaman. Bul Agrohorti. 2(1):22-30.

Ilyas, S. 2006. Seed treatments using matriconditioning to improve vegetable seed quality [ulas balik]. Bul Agron. 34(2):124-132.

Ilyas, S. 2012. Ilmu dan Teknologi Benih: Teori dan Hasil-Hasil Penelitian. IPB Press. Bogor.

Louws, F.J., G.J. Holmes, J.B. Ristaino. 2002. Phytophthora blight of pepper and cucurbits. Vegetable disease information Note 27. College of Agriculture and Life science, Plant Pathology Extension, North Carolina State University: p:14.

Manohara, D. 1988. Ekologi Phytophthora palmivora (Bulter), penyebab penyakit 
busuk pangkal batang lada (Piper nigrum L.). Disertasi. Sekolah Pascasarjana Institut Pertanian Bogor. Bogor.

McMillan, S. 2007. Promoting Growth with PGPR. Soil Foodweb. Canada Ltd. Soil Biology Laboratory and Learning Center.

Miller, S.A., C.R. Randall, M.R. Richard. 1996. Phytophthora blight of pepper and cucurbits HYG-3116-96. Plant Pathology. The Ohio State University Extension, 2021 Coffey Road, Columbus, OH 43210-1087.

Roberts, P.D., R.J. McGovern, T.A. Kucharek, D.J. Mitchell. 2000. Vegetable diseases caused by Phytophthora capsici in Florida. Plant Pathology Department, University of Florida, Gainesville.

Sutariati, G.A.K., Widodo, Sudarsono, S. Ilyas. 2006a. Karakter fisiologis dan keefektifan isolat rizobakteri sebagai agens antagonis Colletotrichum capsici dan rizobakteri pemacu pertumbuhan tanaman cabai. Jurnal Ilmiah Pertanian Kultura. 41(1):28-34.

Sutariati, G.A.K., Widodo, Sudarsono, S. Ilyas. 2006b. Pengaruh perlakuan rizobakteri pemacu pertumbuhan tanaman terhadap viabilitas benih serta pertumbuhan bibit tanaman cabai. Bul Agron. 34(1):46-54.

Syamsuddin. 2010. Perlakuan benih untuk pengendalian penyakit busuk phytophthora, peningkatan hasil dan mutu benih cabai merah (Capsicum aпnиит L). Disertasi. Sekolah Pascasarjana Institut Pertanian Bogor. Bogor. 201 hal.

Tenuta, M. 2004. Plant growth promoting rhizobacteria: prospects for increasing nutrient acquisition and disease control. Department of Soil Science, University of Manitoba. http://www. umanitoba. ca/faculties/afs/MAC_proceedings/ 2003/pdf/tenuta_rhizobacteria.pdf. [28 Maret 2015].

Wiyono, S. 2011. Liputan khusus: kendalikan hama dan penyakit, harga cabai terkendali. Tabloid Agrina. 17 Januari 2011; http:// www.agrina-online.com/ redesign2.php?rid=19\&aid $=2813 . \quad[3$ April 2015].

Yunianti, R., S. Sastrosumarjo, S. Sujiprihati, M. Surahman, S.H. Hidayat. 2007. Ketahanan 22 genotipe cabai (Capsicum spp.) terhadap Phytophthora capsici Leonian dan keragaman genetiknya. Bul Agron. (35) (2): 103-111. 